\title{
Insulin resistance, high prevalence of diabetes, and cardiovascular risk in immigrant Asians.
}

\author{
Genetic or environmental effect?
}

\author{
Jatinder Dhawan, Colin L Bray, Ray Warburton, Daljit S Ghambhir, Julie Morris
}

\begin{abstract}
Objectives-To compare the prevalence of diabetes, hyperinsulinaemia, and associated metabolic abnormalities in immigrant Asians, Asians in India, and native white British men.

Design-Case control study.

Setting-Wythenshawe Hospital, Manchester, United Kingdom, and Maulana Azad Medical School, New Delhi, India.

Subjects-Men with angiographically proved coronary artery disease; 83 British Asians, 87 white men, and 30 Indian Asians with age matched controls. Interventions-Fasting lipid concentrations, serum glucose, and total insulin concentrations were measured in the fasting state and one and two hours after a $75 \mathrm{~g}$ glucose load by mouth. All subjects had a physical examination by the same observer.
\end{abstract}

Results-Asians in the United Kingdom and in India had a higher prevalence of diabetes and impaired glucose tolerance than the white British men. Patients in all three ethnic groups had higher total insulin concentrations than their controls in the fasting state and after the glucose load. British Asian and Indian Asian patients and controls had higher total insulin concentrations than the white men in the fasting state and after the glucose load. Total insulin concentrations were similar in British and Indian Asians, though fasting concentrations were higher in British Asians than Indian Asians. White men had similar cholesterol, lower triglyceride, and higher high density lipoprotein cholesterol concentrations than Asians in the United Kingdom and in India. British Asian patients had higher cholesterol concentrations and British Asian controls had higher triglyceride concentrations than the Indian Asian groups. Asian patients and controls were more active. British and Indian Asian patients had higher waist to hip ratios than controls. The waist to hip ratio was positively correlated with insulin and triglyceride concentrations and negatively correlated with the high density lipoprotein cholesterol concentration. Fasting insulin and high density lipoprotein concentrations were independent predictors of coronary artery disease in white men, whereas in British Asians the waist to hip ratio was the strongest independent predictor. In
Indian Asians the waist to hip ratio and high density lipoprotein concentration were independent predictors of coronary artery disease.

Conclusions-Central obesity in the subgroups of Asians studied showed a close association with hyperinsulinaemia and the risk of coronary artery disease. A predisposition to insulin resistance and its metabolic abnormalities in this group of Asians seems to be genetically determined, environmental changes after migration having only a small additional effect.

(Br Heart f 1994;72:413-421)

The United Kingdom has one of the highest death rates from coronary artery disease. Evidence has emerged that male and female migrants from the Indian subcontinent have a higher mortality from coronary artery disease than the native white population. ${ }^{12}$ Immigrants from the Indian subcontinent belong to differing geographical, cultural, and religious groups; however, the high mortality is shared by the various groups of Asians. ${ }^{34}$

Established risk factors such as increased plasma cholesterol concentrations, hypertension, and smoking do not explain this high mortality from coronary artery disease in immigrant Asians. ${ }^{1}$ Studies in Asian communities in the United Kingdom have suggested that a higher prevalence of non-insulin dependent diabetes mellitus, lower plasma high density lipoprotein cholesterol concentrations, and higher plasma triglyceride concentrations may be additional risk factors for coronary artery disease in this racial group..$^{5-7}$ Insulin resistance has been suggested as the underlying common mechanism in immigrant Asians, leading to diabetes mellitus and lipid abnormalities. ${ }^{7}$ Hyperinsulinaemia has also been shown in survivors of first myocardial infarction in Asians in the United Kingdom compared with the native white population. ${ }^{5}$

Hughes et $a l^{8}$ have reported that first myocardial infarction in mainly Gujarati Asians from London occurs at a significantly younger age than in white subjects. Hughes et $a l^{5}$

reported significantly higher concentrations of insulin in Asians than in white survivors of first myocardial infarction. Only two hour insulin concentrations after glucose given by mouth were measured in their study. They suggested that insulin may be responsible for \\ 21 April 1994
}


"atherogenic" lipid abnormalities in the Asian patients studied, and also for enhanced atherosclerosis and, as a consequence, the increased mortality from coronary artery disease seen in Asian immigrants.

Central obesity has been associated with hyperinsulinaemia ${ }^{9}$ and it has been suggested that the over production of insulin may act as an energy conserving mechanism under conditions of periodic famine and low energy intake. It has also been suggested that non-insulin dependent diabetes and other disturbances associated with insulin resistance and central obesity are consequences of environmental influences, such as low physical activity and high energy intake, in Asian immigrants transported into urban British life. ${ }^{67}$

This supposition is only speculative as there are no studies comparing Asians in the Indian subcontinent with Asians in the United Kingdom.

The present work seeks differences in coronary risk factors and the role of insulin resistance, central obesity, and physical activity in patients with coronary artery disease and controls in Asians in the United Kingdom and in India, and explores any effect of environment on these abnormalities after migration.

\section{Subjects and methods} SUBJECTS

Consecutive series of male British Asian patients referred for diagnostic coronary angiography for chest pain between January 1988 and March 1990 were included if they fulfilled the following criteria: (a) $50 \%$ or more stenosis in one or more major epicardial coronary arteries; and (b) permanent resident of the United Kingdom. Patients with familial hypercholesterolaemia and those being investigated for a valve disorder but with additional coronary artery disease were excluded.

White patients were randomly selected from the catheter laboratory register throughout the period of the study using the same criteria.

Consecutive series of Indian Asian patients having diagnostic coronary angiography in the G B Pant Cardiac Centre and Maulana Azad Medical School, New Delhi, India, between 24 December 1989 and 24 January 1990 were included in the study using the same angiographic criteria.

CONTROLS

Controls from the United Kingdom were recruited from the lists of five local general practices. They were randomly selected and as far as possible age matched with their respective patient group. After review of the medical records the following patients were excluded: those with a documented history of myocardial infarction, angina, or stroke; those with a primary lipid disorder; patients with hypertension receiving treatment; and temporary residents. Age matched Indian Asian controls were recruited randomly from the minor surgical outpatients clinic of the same hospital from which patients were recruited. Similar appropriate exclusions were observed as in the controls from the United Kingdom.

PROCEDURE

After an overnight fast, subjects attended between 8.30 am and 9.30am and a fasting (venous) blood sample was taken. Anhydrous dextrose $(75 \mathrm{~g})$ diluted in $500 \mathrm{ml}$ water was then ingested by all subjects. Further blood samples were taken after 60 and 120 minutes; the 60 minute sample was omitted in the Indian Asians. Those patients receiving a thiazide diuretic were asked not to take this drug for three days before blood sampling and those receiving $\beta$ blockers had their treatment substituted with a calcium antagonist one month before blood sampling in view of the influence of these drugs on serum lipid concentrations. ${ }^{10-11}$ Patients with non-insulin dependent diabetes were asked to omit all hypoglycaemic drugs for 24 hours (48 hours for chlorpropamide). Blood samples were not taken from three British Asian patients with insulin dependent diabetes.

A detailed history was taken of demographic details, medical history, smoking habits, social class, and exercise. "Non-sedentary" was defined as those who were either on their feet most of the day as part of their job, or taking regular physical exercise (at least once a week for at least 20 minutes); "sedentary" was defined as those who were on their feet for less than half the day as part of their job and not taking any form of regular exercise. Patients were asked about their levels of physical activity before the onset of their symptoms.

\section{LABORATORY MEASUREMENTS}

All laboratory analyses for British Asians and white patients were performed within 24 hours of sampling, except for the insulin measurements, for which serum was separated immediately and stored at $-20^{\circ} \mathrm{C}$ and measurements made within three to five weeks. For Indian Asians, plasma glucose was measured within 24 hours of sampling; serum for insulin measurement was stored at $-20^{\circ} \mathrm{C}$ and transported to the United Kingdom on dry ice. Serum for lipid measurement was transported in an insulated box to the laboratory in the United Kingdom. Blood for lipid measurement was taken after overnight fasting in Indian Asians, no more than four days before transporting the samples to the United Kingdom.

Serum glucose was measured by an automated glucose oxidase method. Subjects were classified as normoglycaemic if their two hour serum glucose concentration was less than $7 \cdot 8$ $\mathrm{mmol} / \mathrm{l}$ or as having impaired glucose tolerance if their glucose concentration was greater than or equal to $7 \cdot 8 \mathrm{mmol} / \mathrm{l}$ and less than 11.1 $\mathrm{mmol} / 1$. Subjects were classified as diabetic if their glucose concentration was greater than or equal to $11.1 \mathrm{mmol} / 1$ after glucose challenge. ${ }^{12}$

Plasma total insulin was measured by 
Map of Indian subcontinent showing the origin of Asians studied from the UK and India.

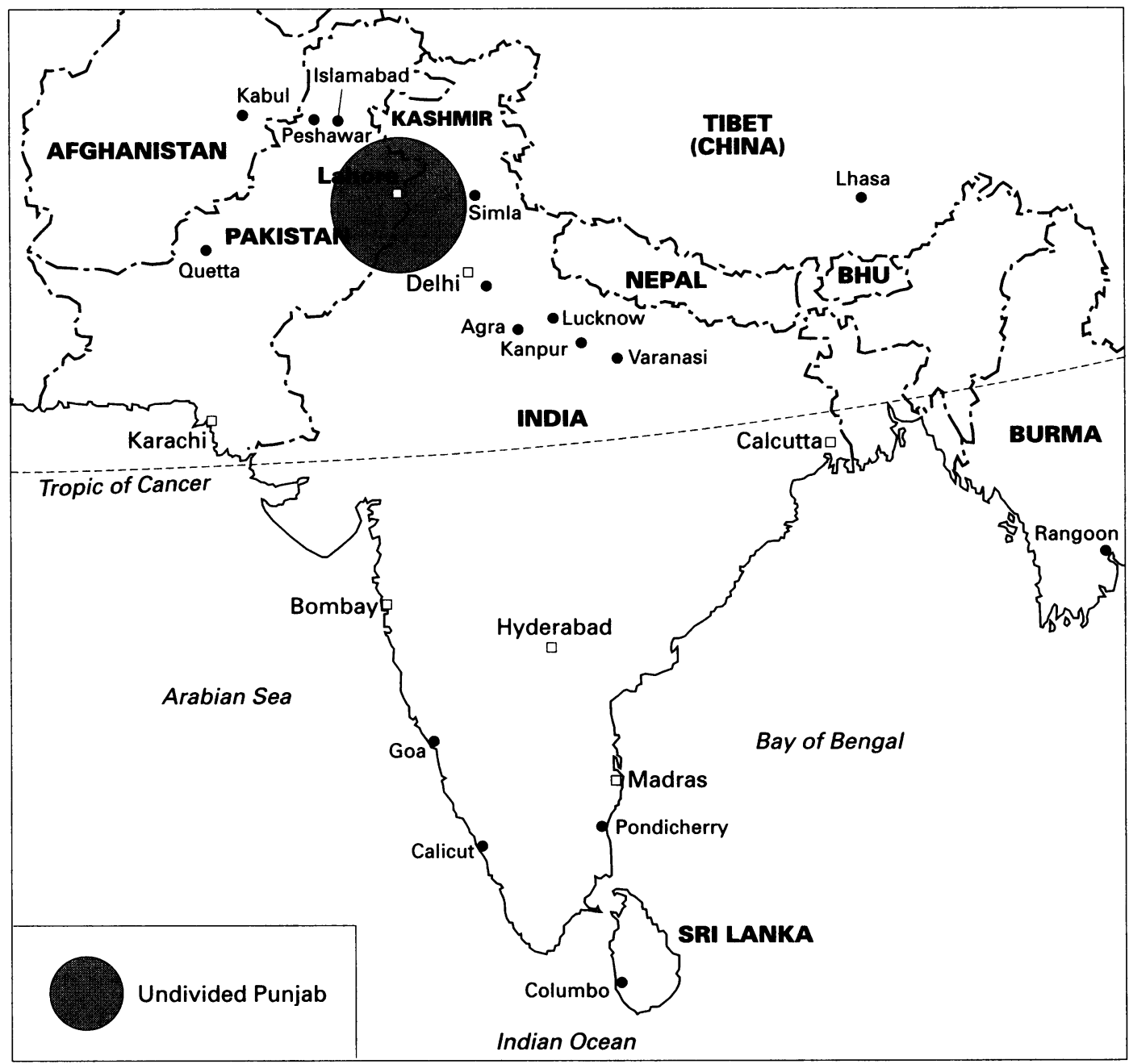

radioimmunoassay using a commercially available kit (Diagnostic Products Limited); the tests were performed in duplicate. The interassay variability was less than $6 \%$ throughout. All measurements were performed in the same laboratory at Wythenshawe Hospital by the same biochemist (RW).

Data were analysed using the SPSSX software program. Group means were compared using unpaired Student's $t$ tests; where appropriate, the raw data were log transformed to normalise distributions. Distributions were compared using $\chi^{2}$ tests. Unconditional logistic regression analysis was performed to examine the relation between risk factors within the study groups. The relative risk of coronary atherosclerosis in each ethnic group was computed on univariate analysis. Multiple regression analysis was performed by a backwards stepwise method in an attempt to assess the relative influence of each risk factor on the presence of coronary atheroma in each patient group.

Eighty three male British Asian and 87 white male patients, along with 80 and 81 controls, respectively, 30 male Indian patients, and 30 controls were recruited in the study.

The British Asian patient and control groups consisted predominantly of people who had migrated from the undivided Punjab (now partly in Pakistan and partly in India) (figure). Seventy four British Asian patients

Table 1 Mean (SD) blood pressure and body size morphology, current smokers, and interval (median) between onset of angina and coronary angiography (in patients)

\begin{tabular}{|c|c|c|c|c|c|c|c|}
\hline & \multicolumn{2}{|l|}{ White subjects } & \multicolumn{2}{|l|}{ British Asians } & \multicolumn{2}{|l|}{ Indian Asians } & \multirow[b]{2}{*}{ PValue ${ }^{*}$} \\
\hline & $\begin{array}{l}\text { Patients } \\
(n=87)\end{array}$ & $\begin{array}{l}\text { Controls } \\
(n=81)\end{array}$ & $\begin{array}{l}\text { Patients } \\
(n=83)\end{array}$ & $\begin{array}{l}\text { Controls } \\
(n=80)\end{array}$ & $\begin{array}{l}\text { Patients } \\
(n=30)\end{array}$ & $\begin{array}{l}\text { Controls } \\
(n=30)\end{array}$ & \\
\hline Age (years) & $56 \cdot 7(8 \cdot 7)$ & $56.4(8.9)$ & $51.9(7 \cdot 1)$ & $51 \cdot 6(7 \cdot 7)$ & $50.0(8.6)$ & $49.5(10 \cdot 0)$ & $<0.001$ \\
\hline Height $(\mathrm{cm})$ & $173 \cdot 1(6 \cdot 3)$ & $174.9(6 \cdot 7)$ & $169 \cdot 7(6 \cdot 8)$ & $169 \cdot 1(5 \cdot 6)$ & $169 \cdot 5(5 \cdot 3)$ & $168.6(5.8)$ & $<0.01$ \\
\hline Weight (kg) & $76.9(11.0)$ & $76 \cdot 1(9 \cdot 2)$ & $73.5(9 \cdot 1)$ & $70 \cdot 4(7 \cdot 9)$ & $68 \cdot 7(8 \cdot 7)$ & $68 \cdot 5(8 \cdot 2)$ & $<0.001$ \\
\hline $\mathrm{BMI}\left(\mathrm{kg} / \mathrm{m}^{2}\right)$ & $25 \cdot 7(3 \cdot 2)$ & $24.9(2.4)$ & $25.5(9.9)$ & $24 \cdot 6(2 \cdot 2)$ & $23.9(2.9)$ & $24 \cdot 1(2 \cdot 7)$ & 0.02 \\
\hline WHR & $0.97(0.06)$ & $0.96(0.05)$ & $1.02(0.05)$ & $0.97(0.75)$ & $1.00(0 \cdot 6)$ & $0.96(0.06)$ & $<0.001$ \\
\hline Systolic BP $(\mathrm{mm} \mathrm{Hg})$ & $137 \cdot 8(24 \cdot 4)$ & $137.0(16.6)$ & $130 \cdot 2(20 \cdot 6)$ & $122 \cdot 1(18 \cdot 0)$ & $138 \cdot 0(19 \cdot 5)$ & $132.5(18 \cdot 8)$ & $<0.01$ \\
\hline Diastolic BP (mm Hg) & $81.8(10.5)$ & $82 \cdot 4(7 \cdot 8)$ & $79 \cdot 1(8 \cdot 3)$ & $77 \cdot 9(7 \cdot 3)$ & $81 \cdot 0(7 \cdot 2)$ & $80 \cdot 5(6 \cdot 5)$ & $<0.05$ \\
\hline Time in United Kingdom (yr) & - & - & $27 \cdot 4(5.9)$ & $27 \cdot 2(7 \cdot 3)$ & - & - & NS \\
\hline Non-sedentary $(\%)$ & $32 / 37(37)$ & $30 / 87(34)$ & $19 / 83(23)$ & $14 / 80$ (17) & $16 / 30(53)$ & $20 / 30(67)$ & $<0.01$ \\
\hline Mean lifetime cigarette & & & & & & & \\
\hline $\begin{array}{l}\text { consumption of ex-smokers } \\
\text { and current Smokers (1000s) }\end{array}$ & $212(164 \cdot 267)$ & $160(121-204)$ & $159(121-203)$ & $139(92-196)$ & $150(77-246)$ & $85(52-127)$ & NS \\
\hline
\end{tabular}

BMI = Body mass index; WHR $=$ weight to height ratio; $\mathrm{BP}=$ blood pressure. ${ }^{\star}$ Analysis of variance. 
Table 2 Social class distribution (\%)

\begin{tabular}{|c|c|c|c|c|c|c|}
\hline & \multicolumn{2}{|c|}{ White subjects } & \multicolumn{2}{|c|}{ British Asians } & \multicolumn{2}{|c|}{ Indian Asians } \\
\hline & $\begin{array}{l}\text { Patients } \\
(n=87)\end{array}$ & $\begin{array}{l}\text { Controls } \\
(n=81)\end{array}$ & $\begin{array}{l}\text { Patients } \\
(n=83)\end{array}$ & $\begin{array}{l}\text { Controls } \\
(n=80)\end{array}$ & $\begin{array}{l}\text { Patients } \\
(n=30)\end{array}$ & $\begin{array}{l}\text { Controls } \\
(n=30)\end{array}$ \\
\hline $\begin{array}{l}\text { Social class } 1 \\
\text { Social class } 2 \\
\text { Social class } 3 \\
\text { Social class } 4\end{array}$ & $\begin{array}{r}11 \\
38 \\
44 \\
7\end{array}$ & $\begin{array}{r}12 \\
37 \\
48 \\
3\end{array}$ & $\begin{array}{r}12 \\
34 \\
47 \\
7\end{array}$ & $\begin{array}{r}12 \\
34 \\
48 \\
6\end{array}$ & $\begin{array}{l}3 \\
41 \\
44 \\
12\end{array}$ & $\begin{array}{r}7 \\
40 \\
37 \\
16\end{array}$ \\
\hline
\end{tabular}

$\chi^{2}(15)=10.5 ; P=0.78$.

Table 3 Difference in the prevalence of diabetes, impaired glucose tolerance, and normoglycaemia. Values are No (\%)

\begin{tabular}{|c|c|c|c|c|c|c|}
\hline & \multicolumn{2}{|c|}{ White subjects } & \multicolumn{2}{|c|}{ British Asians } & \multicolumn{2}{|c|}{ Indian Asians } \\
\hline & $\begin{array}{l}\text { Patients } \\
\qquad(n=87)\end{array}$ & $\begin{array}{l}\text { Controls } \\
(n=81)\end{array}$ & $\begin{array}{c}\text { Patients } \\
(n=83)\end{array}$ & $\begin{array}{l}\text { Controls } \\
(n=80)\end{array}$ & $\begin{array}{l}\text { Patients } \\
(n=30)\end{array}$ & $\begin{array}{l}\text { Controls } \\
(n=30)\end{array}$ \\
\hline $\begin{array}{l}\text { Diabetic } \\
\text { Impaired glucose } \\
\text { tolerance }\end{array}$ & $\begin{array}{c}7(8) \\
15(17)\end{array}$ & $\begin{array}{l}2(2) \\
6(7)\end{array}$ & $\begin{array}{l}21(25) \\
19(23)\end{array}$ & $\begin{array}{r}9(11) \\
16(20)\end{array}$ & $\begin{array}{r}10(33) \\
7(23)\end{array}$ & $\begin{array}{l}5(17) \\
5(17)\end{array}$ \\
\hline Normoglycaemic & $65(75)$ & $73(90)$ & $43(52)$ & $55(69)$ & $13(43)$ & $20(67)$ \\
\hline
\end{tabular}

$\chi^{2}(5)=30 \cdot 6 ; P=0.00001$. nated from a similar geographical area in the Indian subeontinent. The British Asian patients and controls had been resident in the United Kingdom for a similar length of time (table 1).

British Asian patients and controls were younger, shorter, and lighter in weight than their comparative white patients. No significant difference in age, height, or weight was seen between Indian Asians and British Asians. Social class in the three ethnic groups was similar (table 2) and smoking rates were also similar (table 1). Body mass index was similar in the different racial groups; however, within groups British Asian patients had a higher body mass index than their controls. The only differences in systolic and diastolic blood pressure were between British Asian and white controls (being lower in British Asians).

Table 4 Geometric means (95\% confidence intervals) of glucose and insulin concentrations at fasting and one and two hours after glucose load by mouth

\begin{tabular}{|c|c|c|c|c|c|c|c|}
\hline & \multicolumn{2}{|l|}{ White subjects } & \multicolumn{2}{|l|}{ British Asians } & \multicolumn{2}{|l|}{ Indian Asians } & \multirow[b]{2}{*}{$P$ Value $e^{\star}$} \\
\hline & $\begin{array}{l}\text { Patients } \\
(n=87)\end{array}$ & $\begin{array}{l}\text { Controls } \\
(n=81)\end{array}$ & $\begin{array}{l}\text { Patients } \\
(n=83)\end{array}$ & $\begin{array}{l}\text { Controls } \\
(n=80)\end{array}$ & $\begin{array}{l}\text { Patients } \\
(n=30)\end{array}$ & $\begin{array}{l}\text { Controls } \\
(n=30)\end{array}$ & \\
\hline \multicolumn{8}{|l|}{$\begin{array}{l}\text { Glucose } \\
(\mathrm{mmol} / \mathrm{l})\end{array}$} \\
\hline $\begin{array}{l}\text { Fasting } \\
\text { One hour } \\
\text { Two hour }\end{array}$ & $\begin{array}{l}4.77(4 \cdot 5 \text { to } 5 \cdot 0) \\
7 \cdot 76(7 \cdot 22 \text { to } 8 \cdot 32) \\
6 \cdot 13(5 \cdot 61 \text { to } 6 \cdot 70)\end{array}$ & $\begin{array}{l}4 \cdot 40(4 \cdot 2 \text { to } 4 \cdot 61) \\
7 \cdot 24(6 \cdot 74 \text { to } 7 \cdot 77) \\
5 \cdot 19(4 \cdot 30 \text { to } 5 \cdot 61)\end{array}$ & $\begin{array}{l}5.34(4.97 \text { to } 5.74) \\
9.88(9 \cdot 17 \text { to } 10.66) \\
7.37(6.64 \text { to } 8.19)\end{array}$ & $\begin{array}{l}4.91(4.53 \text { to } 5.32) \\
8.39(7.73 \text { to } 9.10) \\
6.34(5.69 \text { to } 6.84)\end{array}$ & $\begin{array}{r}5.58(4.87 \text { to } 6.39) \\
-\quad 8.08(6.79 \text { to } 9.65)\end{array}$ & $\begin{array}{l}5.01(4.45 \text { to } 5.64) \\
-\quad 7.25(6.3 \text { to } 8.35)\end{array}$ & $\begin{array}{l}\text { NS } \\
<0 \cdot 05 \\
<0 \cdot 10\end{array}$ \\
\hline \multicolumn{8}{|c|}{$\begin{array}{l}\text { Insulin } \\
(\mu \mathrm{U} / \mathrm{ml})\end{array}$} \\
\hline Fasting & $12.7(10.8$ to 14.9$)$ & $7.6(6.5$ to 8.8$)$ & $28.2(24.5$ to $31 \cdot 8)$ & $18.6(16.4$ to 20.9$)$ & $18 \cdot 4(15.6$ to $21 \cdot 6)$ & $14 \cdot 2(12 \cdot 1$ to $16 \cdot 6)$ & $<0.001$ \\
\hline One hour & $72.7(63.0$ to 83.8$)$ & $51.6(44.9$ to $59 \cdot 3)$ & $122.0(104.8$ to $142 \cdot 0)$ & $90.0(79.3$ to $102 \cdot 3)$ & & & $<0.05$ \\
\hline Two hour & $43.5(36.5$ to $51 \cdot 9)$ & $26.8(22.2$ to 32.3$)$ & $83.3(70.2$ to 96.4$)$ & $58 \cdot 0(51 \cdot 2$ to $65 \cdot 1)$ & $8 \cdot 62(6 \cdot 12$ to $12 \cdot 10)$ & $6.53(4.92$ to 8.66$)$ & $<0.05$ \\
\hline
\end{tabular}

^Analysis of variance.

Table 5 Geometric mean (95\% confidence intervals) of insulin concentrations ( $\mu U / \mathrm{ml}$ ) at fasting and one and two hours after glucose given by mouth by glucose tolerance categories

\begin{tabular}{|c|c|c|c|c|c|c|c|}
\hline & \multicolumn{2}{|l|}{ White subjects } & \multicolumn{2}{|l|}{ British Asians } & \multicolumn{2}{|l|}{ Indian Asians } & \multirow[b]{2}{*}{$\begin{array}{l}\text { Significance } \\
P<0.05\end{array}$} \\
\hline & $\begin{array}{l}\text { (a) } \\
\text { Patients } \\
(n=87)\end{array}$ & $\begin{array}{l}\text { (b) } \\
\text { Controls } \\
(n=81)\end{array}$ & $\begin{array}{l}\text { (c) } \\
\text { Patients } \\
(n=83)\end{array}$ & $\begin{array}{l}\text { (d) } \\
\text { Controls } \\
(n=80)\end{array}$ & $\begin{array}{l}\text { (e) } \\
\text { Patients } \\
(n=30)\end{array}$ & $\begin{array}{l}\text { Controls } \\
(n=30)\end{array}$ & \\
\hline \multicolumn{8}{|l|}{ Diabetic } \\
\hline Fasting & $\begin{array}{l}2.90 \\
(13.6 \text { to } 61.9)\end{array}$ & $14 \cdot 7^{\star}$ & $\begin{array}{l}24 \cdot 7 \\
(18.6 \text { to } 32 \cdot 9)\end{array}$ & $\begin{array}{l}33.6 \\
(19 \cdot 6 \text { to } 57 \cdot 6)\end{array}$ & $\begin{array}{l}14.9 \\
(10.7 \text { to } 20.7)\end{array}$ & $\begin{array}{l}14.6 \\
(4.9 \text { to } 42.9)\end{array}$ & \\
\hline One hour & $\begin{array}{l}84 \cdot 0 \\
(47.4 \text { to } 146.9)\end{array}$ & $25 \cdot 9 \star$ & $\begin{array}{l}63 \cdot 1 \\
(41 \cdot 6 \text { to } 94 \cdot 6)\end{array}$ & $\begin{array}{l}69 \cdot 0 \\
(36 \cdot 2 \text { to } 121 \cdot 5)\end{array}$ & - & & \\
\hline Two hour & $\begin{array}{l}70 \cdot 0 \\
(52 \cdot 4 \text { to } 92 \cdot 7)\end{array}$ & $25 \cdot 8^{\star}$ & $\begin{array}{l}53 \cdot 8 \\
(36 \cdot 2 \text { to } 36 \cdot 2 \text { to } 79 \cdot 0)\end{array}$ & $\begin{array}{l}67 \cdot 0 \\
(36 \cdot 2 \text { to } 122 \cdot 7)\end{array}$ & $\begin{array}{l}44 \cdot 4 \\
(29 \cdot 3 \text { to } 66 \cdot 6)\end{array}$ & $\begin{array}{l}32 \cdot 6 \\
(82 \cdot 2 \text { to } 128 \cdot 0)\end{array}$ & \\
\hline \multicolumn{8}{|l|}{$\begin{array}{l}\text { Impaired glucose } \\
\text { tolerance }\end{array}$} \\
\hline Fasting & $\begin{array}{l}17 \cdot 6 \\
(11 \cdot 1 \text { to } 27 \cdot 6)\end{array}$ & $\begin{array}{l}9 \cdot 7 \\
(3 \cdot 7 \text { to } 24 \cdot 7)\end{array}$ & $\begin{array}{l}36 \cdot 3 \\
(26 \cdot 8 \text { to } 48 \cdot 4)\end{array}$ & $\begin{array}{l}24 \cdot 0 \\
(18 \cdot 7 \text { to } 30 \cdot 5)\end{array}$ & $\begin{array}{l}25 \cdot 1 \\
(17 \cdot 9 \text { to } 34 \cdot 4)\end{array}$ & $\begin{array}{l}17 \cdot 0 \\
(12 \cdot 4 \text { to } 23 \cdot 0)\end{array}$ & $c>a$ \\
\hline One hour & $\begin{array}{l}85 \cdot 6 \\
(55 \cdot 1 \text { to } 131 \cdot 6)\end{array}$ & $\begin{array}{l}72 \cdot 1 \\
(38 \cdot 1 \text { to } 134 \cdot 2)\end{array}$ & $\begin{array}{l}172.2 \\
(138.3 \text { to } 210.6)\end{array}$ & $\begin{array}{l}117 \cdot 2 \\
(95.5 \text { to } 141 \cdot 1)\end{array}$ & - & - & $c>a$ \\
\hline Two hour & $\begin{array}{l}87 \cdot 2 \\
(60 \cdot 9 \text { to } 123.9)\end{array}$ & $\begin{array}{l}59 \cdot 2 \\
(26 \cdot 8 \text { to } 129 \cdot 0)\end{array}$ & $\begin{array}{l}120.4 \\
(93.6 \text { to } 152.9)\end{array}$ & $\begin{array}{l}84 \cdot 6 \\
(69 \cdot 4 \text { to } 102 \cdot 5)\end{array}$ & $\begin{array}{l}133.2 \\
(90.0 \text { to } 196.3)\end{array}$ & $\begin{array}{l}99 \cdot 8 \\
(89 \cdot 1 \text { to } 111 \cdot 0)\end{array}$ & \\
\hline \multicolumn{8}{|c|}{13.4} \\
\hline Fasting & $\begin{array}{l}10 \cdot 8 \\
(9 \cdot 1 \text { to } 12 \cdot 1)\end{array}$ & $\begin{array}{l}7 \cdot 3 \\
(6 \cdot 1 \text { to } 8 \cdot 5)\end{array}$ & $\begin{array}{l}26 \cdot 6 \\
(22 \cdot 6 \text { to } 30 \cdot 8)\end{array}$ & $\begin{array}{l}15 \cdot 6 \\
(13 \cdot 8 \text { to } 17 \cdot 4)\end{array}$ & $\begin{array}{l}18 \cdot 3 \\
(14 \cdot 5 \text { to } 22 \cdot 8)\end{array}$ & $\begin{array}{l}13.4 \\
(11.5 \text { to } 15 \cdot 3)\end{array}$ & $\begin{array}{l}c>d, c>a \\
d>b, a>b\end{array}$ \\
\hline One hour & $\begin{array}{l}68 \cdot 8 \\
(58 \cdot 5 \text { to } 80 \cdot 6)\end{array}$ & $\begin{array}{l}51.2 \\
(43.8 \text { to } 59 \cdot 1)\end{array}$ & $\begin{array}{l}138 \cdot 4 \\
(116 \cdot 7 \text { to } 160 \cdot 7)\end{array}$ & $\begin{array}{l}87 \cdot 2 \\
(74 \cdot 4 \text { to } 100 \cdot 4)\end{array}$ & & & $\begin{array}{l}c>a, d>b \\
c>d, a>b\end{array}$ \\
\hline Two hour & $\begin{array}{l}35 \cdot 2 \\
(28 \cdot 7 \text { to } 42 \cdot 5)\end{array}$ & $\begin{array}{l}25 \cdot 1 \\
(20 \cdot 5 \text { to } 30 \cdot 2)\end{array}$ & $\begin{array}{l}83 \cdot 1 \\
(67 \cdot 3 \text { to } 101 \cdot 5)\end{array}$ & $\begin{array}{l}50 \cdot 4 \\
(44 \cdot 2 \text { to } 57 \cdot 3)\end{array}$ & $\begin{array}{l}69 \cdot 4 \\
(48 \cdot 4 \text { to } 98 \cdot 5)\end{array}$ & $\begin{array}{l}43 \cdot 1 \\
(31 \cdot 2 \text { to } 58 \cdot 5)\end{array}$ & $\begin{array}{l}c>a, d>b \\
c>d, a>b\end{array}$ \\
\hline
\end{tabular}

*Insufficient number for confidence intervals.

had migrated from the Punjab and nine migrated from elsewhere to the United Kingdom (Gujarat, Kenya, Bangladesh); there were 75 British Asian controls who had migrated from the Punjab and five from elsewhere. All the patients and controls studied in Delhi, India, had migrated from the Punjab in 1947 after the partition of India. Thus most British Asians and Indian Asians had origi-
A striking difference was seen in the waist to hip ratio. Patients had a higher waist to hip ratio than controls in both the Asian groups; British Asian patients and controls had higher waist to hip ratios than white patients. Asian patients and controls from the United Kingdom had similar waist to hip ratios to Asians from India (table 1).

The prevalence of diabetes and impaired 
Table 6 Mean (SD or 95\% confidence intervals) cholesterol and triglyceride concentrations in patients and controls (all values mmol/l)

\begin{tabular}{|c|c|c|c|c|c|c|c|}
\hline & \multicolumn{2}{|l|}{ White subjects } & \multicolumn{2}{|l|}{ British Asians } & \multicolumn{2}{|l|}{ Indian Asians } & \multirow[b]{2}{*}{ PValue * } \\
\hline & $\begin{array}{l}\text { Patients } \\
(n=87)\end{array}$ & $\begin{array}{l}\text { Controls } \\
(n=81)\end{array}$ & $\begin{array}{l}\text { Patients } \\
(n=83)\end{array}$ & $\begin{array}{l}\text { Controls } \\
(n=80)\end{array}$ & $\begin{array}{l}\text { Patients } \\
(n=30)\end{array}$ & $\begin{array}{l}\text { Controls } \\
(n=30)\end{array}$ & \\
\hline $\begin{array}{l}\text { Total cholesterol } \\
\text { Log HDL cholesterol } \\
\text { Total cholesterol/ }\end{array}$ & $\begin{array}{l}6.32(1.14) \\
1.08(1.02 \text { to } 1.14)\end{array}$ & $\begin{array}{l}6.08(0.90) \\
1.29(1.22 \text { to } 1.36)\end{array}$ & $\begin{array}{l}6.16(1.09) \\
1.02(0.97 \text { to } 1.07)\end{array}$ & $\begin{array}{l}5.69(0.96) \\
1.07(1.02 \text { to } 1.12)\end{array}$ & $\begin{array}{l}5.44(1.06) \\
0.89(0.81 \text { to } 0.98)\end{array}$ & $\begin{array}{l}5.04(1.05) \\
1.22(1.11 \text { to } 1.35)\end{array}$ & $\begin{array}{l}<0.05 \\
<0.01\end{array}$ \\
\hline $\begin{array}{l}\text { HDL cholesterol } \\
\text { Log triglyceride }\end{array}$ & $\begin{array}{l}6.06(1.95) \\
1.79(1.60 \text { to } 2.01)\end{array}$ & $\begin{array}{l}4.88(1.48) \\
1.30(1.19 \text { to } 1.43)\end{array}$ & $\begin{array}{l}6.11(1.49) \\
2.39(1.64 \text { to } 2 \cdot 16)\end{array}$ & $\begin{array}{l}5.41(1.30) \\
1.84(1.66 \text { to } 2.03)\end{array}$ & $\begin{array}{l}6.09(1.32) \\
1.91(1.68 \text { to } 2.19)\end{array}$ & $\begin{array}{l}4.20(1.20) \\
1.38(1.16 \text { to } 1.64)\end{array}$ & $\begin{array}{l}<0.001 \\
<0.01\end{array}$ \\
\hline
\end{tabular}

HDL $=$ High density lipoprotein

$\star$ Analysis of variance.

Table 7 Comparison between sedentary and non-sedentary subjects with respect to insulin concentrations, body mass index, lipids, and blood pressure. Values are mean (SD or $95 \%$ confidence intervals)

\begin{tabular}{|c|c|c|c|}
\hline & \multicolumn{2}{|l|}{ All subjects } & \multirow[b]{2}{*}{ Pvalue } \\
\hline & $\begin{array}{l}\text { Sedentary } \\
(n=260)\end{array}$ & $\begin{array}{l}\text { Non-sedentary } \\
(n=131)\end{array}$ & \\
\hline \multicolumn{4}{|l|}{ Log insulin concentrate $(\mu \mathrm{U} / \mathrm{ml})$} \\
\hline Fasting & $17 \cdot 1(15 \cdot 6$ to $18 \cdot 7)$ & $11.6(10.3$ to 12.9$)$ & $<0.0001$ \\
\hline One hour & $88.2(80 \cdot 6$ to $92 \cdot 7)$ & $62 \cdot 1(54 \cdot 5$ to $70 \cdot 8)$ & $<0.001$ \\
\hline Two hours & $57.9(52.4$ to 64.0$)$ & $36 \cdot 2(29 \cdot 3$ to $37 \cdot 3)$ & $<0.001$ \\
\hline BMI $\left(\mathrm{kg} / \mathrm{m}^{2}\right)$ & $25 \cdot 53(0 \cdot 16)$ & $23.95(0.23)$ & $<0.001$ \\
\hline Total cholesterol $(\mathrm{mmol} / \mathrm{l})$ & $5.97(0.06)$ & $5.88(0.10)$ & NS \\
\hline Log triglyceride $(\mathrm{mmol} / \mathrm{l})$ & $1.85(1.73$ to 1.95$)$ & $1.60(1.50$ to 1.69$)$ & $<0.01$ \\
\hline Log HD̄ cholesterol (mmol//) & $1.08(1.06$ to 1.10$)$ & $1 \cdot 12(1.07$ to $1 \cdot 16)$ & NS \\
\hline Systolic blood pressure ( $\mathrm{mm} \mathrm{Hg}$ ) & $133.9(1.2)$ & $129 \cdot 4(1 \cdot 8)$ & $<0.05$ \\
\hline Diastolic blood pressure $(\mathrm{mm} \mathrm{Hg})$ & $81 \cdot 12(1 \cdot 1)$ & $78.96(1.6)$ & $<0.01$ \\
\hline
\end{tabular}

HDL = High density lipoprotein.

glucose tolerance was much higher in British Asians than white patients and even higher in Indian Asians. Only $43 \%$ of Indian Asian patients and $52 \%$ of British Asian patients were normoglycaemic compared with $75 \%$ of white patients (table 3 ).

Fasting serum insulin concentrations were higher in patients than controls in all three racial groups $(P<0.001)$, with British Asian patients having significantly higher concentrations than any other group, and the two Asian groups having significantly higher concentrations than white patients. At one hour after glucose challenge, the patients had higher concentrations than the controls $(P<0.001)$, with British Asians having significantly higher concentrations than white patients (one hour sample was omitted in Indian Asians).

At two hours after the glucose given by mouth, white and British Asian patients had higher concentrations than controls $(P<$ 0.001); Indian Asian patients and controls were not different. Asian groups had signifi- cantly higher concentrations than white patients. Concentrations were comparable in Asians in the United Kingdom and in India (table 4).

As there was a larger proportion of patients with diabetes and impaired glucose tolerance in Asians than white men, the racial groups were subdivided according to glucose category to examine the effect of glucose status on insulin concentrations (table 5). These concentrations were higher in patients with impaired glucose tolerance than in normoglycaemic patients in the same subgroup. Normoglycaemic patients had significantly higher insulin concentrations than controls, except in Indian Asians in fasting, one and two hour samples after glucose by mouth. British Asians and Indian Asians had higher concentrations than white patients at all stages of the oral glucose tolerance test $(P<$ 0.001). Indian Asian non-diabetic patients had higher insulin concentrations than controls at two hours: $87 \cdot 2(65 \cdot 3-115 \cdot 5) v 51 \cdot 0$ (38.0-67.3) $\mu \mathrm{U} / \mathrm{ml}(\mathrm{P}<0.01)$.

\section{LIPIDS}

Triglyceride concentrations were higher in British Asian patients than in any other group except Indian Asian patients $(P<0.01)$. British Asian and white patients had higher concentrations than their controls $(P<0.01)$. In the controls British Asians had significantly higher concentrations than white men and Indian Asians (table 6).

High density lipoprotein concentrations were lower in white patients and Indian Asians than in their controls $(P<0.01)$. White controls had significantly higher concentrations than any other group except

Table 8 Comparison between sedentary and non-sedentary white subjects. Values are mean (SD or 95\% confidence interval)

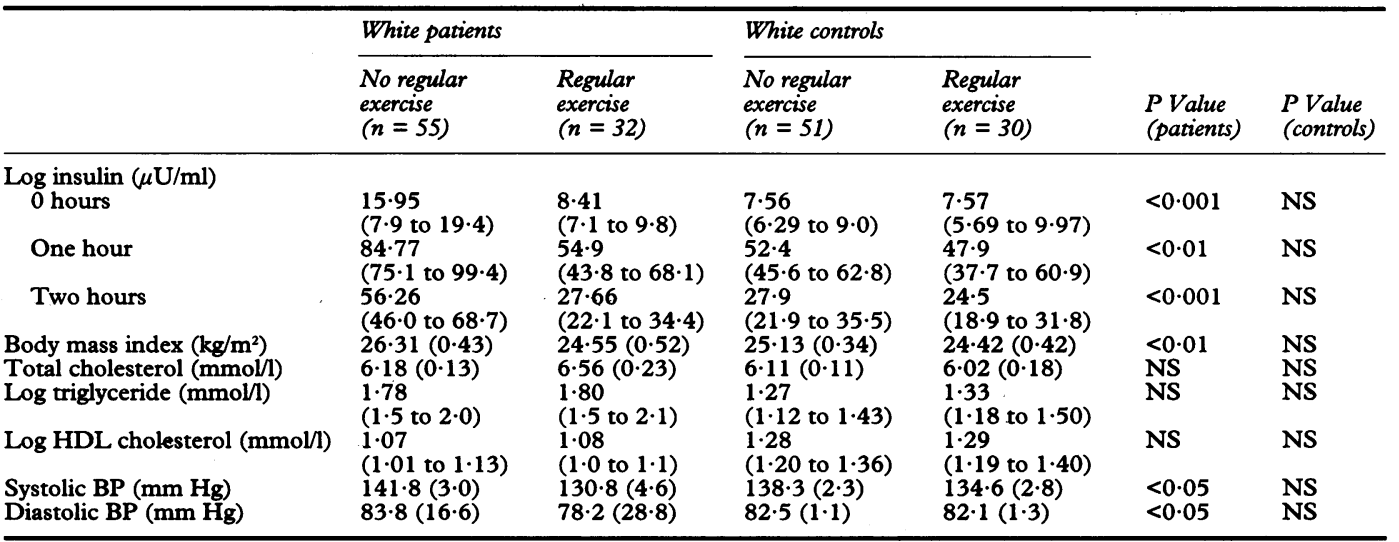

HDL = high density lipoprotein; BP = blood pressure. 
Table 9 Comparison between sedentary and non-sedentary British Asian subjects. Values are mean (SD or $95 \%$ confidence interval)

\begin{tabular}{|c|c|c|c|c|c|c|}
\hline & \multicolumn{2}{|c|}{ British Asian patients } & \multicolumn{2}{|c|}{ British Asian controls } & \multirow[b]{2}{*}{$\begin{array}{l}\text { P Value } \\
\text { (patients) }\end{array}$} & \multirow[b]{2}{*}{$\begin{array}{l}\text { P Value } \\
\text { (controls) }\end{array}$} \\
\hline & $\begin{array}{l}\text { No regular } \\
\text { exercise } \\
(n=61)\end{array}$ & $\begin{array}{l}\text { Regular } \\
\text { exercise } \\
(n=19)\end{array}$ & $\begin{array}{l}\text { No regular } \\
\text { exercise } \\
(n=66)\end{array}$ & $\begin{array}{l}\text { Regular } \\
\text { exercise } \\
(n=14)\end{array}$ & & \\
\hline \multicolumn{7}{|l|}{$\overline{L o g}$ insulin $(\mu \mathrm{U} / \mathrm{ml})$} \\
\hline 0 hours & $\begin{array}{l}31.8 \\
(26.0 \text { to } 36.5)\end{array}$ & $\begin{array}{l}18 \cdot 9 \\
(15 \cdot 1 \text { to } 21 \cdot 7)\end{array}$ & $\begin{array}{l}19 \cdot 6 \\
(17 \cdot 4 \text { to } 22 \cdot 1)\end{array}$ & $\begin{array}{l}13.5 \\
(11 \cdot 1 \text { to } 16 \cdot 6)\end{array}$ & $<0.001$ & $<0.01$ \\
\hline One hour & $\begin{array}{l}127 \cdot 7 \\
(106 \cdot 6 \text { to } 152-9)\end{array}$ & $\begin{array}{l}125 \cdot 2 \\
(77 \cdot 4 \text { to } 135 \cdot 6)\end{array}$ & $\begin{array}{l}93 \cdot 6 \\
(81 \cdot 4 \text { to } 107 \cdot 7)\end{array}$ & $\begin{array}{l}73 \cdot 6 \\
(62 \cdot 8 \text { to } 86 \cdot 4)\end{array}$ & NS & $<0.05$ \\
\hline Two hours & $\begin{array}{l}94.6 \\
(80 \cdot 6 \text { to } 111)\end{array}$ & $\begin{array}{l}50.90 \\
(37.7 \text { to } 68 \cdot 7)\end{array}$ & $\begin{array}{l}60 \cdot 9 \\
(54 \cdot 0 \text { to } 68 \cdot 7)\end{array}$ & $\begin{array}{l}42 \cdot 5 \\
(34 \cdot 4 \text { to } 47 \cdot 4)\end{array}$ & $<0.001$ & $<0.05$ \\
\hline $\begin{array}{l}\text { Body mass index }\left(\mathrm{kg} / \mathrm{m}^{2}\right) \\
\text { Total cholesterol }(\mathrm{mmol} / \mathrm{l}) \\
\text { Log triglyceride }(\mathrm{mmol} / \mathrm{l})\end{array}$ & $\begin{array}{l}25 \cdot 92(0 \cdot 34) \\
6 \cdot 21(0 \cdot 14) \\
2 \cdot 50 \\
(2 \cdot 2 \text { to } 2 \cdot 7)\end{array}$ & $\begin{array}{l}24 \cdot 32(0 \cdot 71) \\
5.96(1 \cdot 8) \\
1.95 \\
(1.6 \text { to } 2 \cdot 3)\end{array}$ & $\begin{array}{l}24.90(0 \cdot 27) \\
5.65(0 \cdot 11) \\
1.82 \\
(1.6 \text { to } 2 \cdot 0)\end{array}$ & $\begin{array}{l}23.05(0 \cdot 48) \\
5 \cdot 88(0 \cdot 29) \\
1.85 \\
(1.6 \text { to } 2 \cdot 1)\end{array}$ & $\begin{array}{l}<0.05 \\
\text { NS } \\
<0.05\end{array}$ & $\begin{array}{l}<0 \cdot 01 \\
\text { NS } \\
\text { NS }\end{array}$ \\
\hline Log HDL cholesterol $(\mathrm{mmol} / \mathrm{l})$ & $\begin{array}{l}1.0 \\
(0.9 \text { to } 1.0)\end{array}$ & $\begin{array}{l}1.09 \\
(1.03 \text { to } 1.16)\end{array}$ & $\begin{array}{l}1.05 \\
(1.01 \text { to } 1.09)\end{array}$ & $\begin{array}{l}1 \cdot 11 \\
(1 \text { to } 1 \cdot 2)\end{array}$ & NS & NS \\
\hline $\begin{array}{l}\text { Systolic BP }(\mathrm{mm} \mathrm{Hg}) \\
\text { Diastolic BP }(\mathrm{mm} \mathrm{Hg})\end{array}$ & $\begin{array}{l}132.5(2 \cdot 6) \\
79 \cdot 9\end{array}$ & $\begin{array}{l}122 \cdot 1(4 \cdot 1) \\
76 \cdot 3\end{array}$ & $\begin{array}{l}124 \cdot 7(2 \cdot 2) \\
78 \cdot 8\end{array}$ & $\begin{array}{l}109 \cdot 7(3 \cdot 1) \\
73 \cdot 5\end{array}$ & $\begin{array}{l}<0.05 \\
\text { NS }\end{array}$ & $\begin{array}{l}<0.01 \\
<0.05\end{array}$ \\
\hline
\end{tabular}

HDL = High density lipoprotein; BP = blood pressure.

Table 10 Comparison between sedentary and non-sedentary Indian Asian subjects. Values are mean (SD or 95\% confidence interval)

\begin{tabular}{|c|c|c|c|c|c|c|}
\hline & \multicolumn{2}{|c|}{ Indian Asian patients } & \multicolumn{2}{|c|}{ Indian Asian controls } & \multirow[b]{2}{*}{$\begin{array}{l}P \text { Value } \\
\text { (patients) }\end{array}$} & \multirow[b]{2}{*}{$\begin{array}{l}\text { PValue } \\
\text { (controls) }\end{array}$} \\
\hline & $\begin{array}{l}\text { No regular } \\
\text { exercise } \\
(n=14)\end{array}$ & $\begin{array}{l}\text { Regular } \\
\text { exercise } \\
(n=16)\end{array}$ & $\begin{array}{l}\text { No regular } \\
\text { exercise } \\
(n=10)\end{array}$ & $\begin{array}{l}\text { Regular } \\
\text { exercise } \\
(n=20)\end{array}$ & & \\
\hline \multicolumn{7}{|l|}{$\log$ insulin $(\mu \mathrm{U} / \mathrm{ml})$} \\
\hline o hour & $\begin{array}{l}16 \cdot 7 \\
(12 \cdot 6 \text { to } 21 \cdot 3)\end{array}$ & $\begin{array}{l}19 \cdot 8 \\
(15 \cdot 1 \text { to } 21 \cdot 7)\end{array}$ & $\begin{array}{l}16 \cdot 1 \\
(14 \cdot 0 \text { to } 18 \cdot 5)\end{array}$ & $\begin{array}{l}13 \cdot 1 \\
(11 \cdot 4 \text { to } 15 \cdot 1)\end{array}$ & NS & NS \\
\hline One hour & & & & & $\overline{20}$ & - \\
\hline Two hours & $\begin{array}{l}64 \cdot 0 \\
(42 \cdot 9 \text { to } 95 \cdot 5)\end{array}$ & $\begin{array}{l}74 \cdot 4 \\
(55 \cdot 1 \text { to } 100 \cdot 4)\end{array}$ & $\begin{array}{l}79.0 \\
(46.9 \text { to } 132.9)\end{array}$ & $\begin{array}{l}36 \cdot 2 \\
(29 \cdot 6 \text { to } 44 \cdot 2)\end{array}$ & NS & $<0.01$ \\
\hline $\begin{array}{l}\text { Body mass index }\left(\mathrm{kg} / \mathrm{m}^{2}\right) \\
\text { Total cholesterol }(\mathrm{mmol} / \mathrm{l}) \\
\text { Log triglyceride }(\mathrm{mmol} / \mathrm{l})\end{array}$ & $\begin{array}{l}25.06(0.7) \\
5.61(0.3) \\
2.33 \\
(1.9 \text { to } 1.1)\end{array}$ & $\begin{array}{l}22.92(0.6) \\
5.28(0 \cdot 2) \\
1.59 \\
(1.3 \text { to } 1.8)\end{array}$ & $\begin{array}{l}25.56(0.53) \\
5.12(0.43) \\
1.58 \\
(1.06 \text { to } 2.3)\end{array}$ & $\begin{array}{l}23.36(0.65) \\
5.00(0.19) \\
1.29 \\
(1.1 \text { to } 1.4)\end{array}$ & $\begin{array}{l}<0.05 \\
\text { NS } \\
<0.01\end{array}$ & $\begin{array}{l}<0 \cdot 05 \\
\text { NS } \\
\text { NS }\end{array}$ \\
\hline Log HDL cholesterol (mmol/l) & $\begin{array}{l}1.04 \\
(0.9 \text { to } 1.1)\end{array}$ & $\begin{array}{l}1.17 \\
(1.0 \text { to } 1.2)\end{array}$ & $\begin{array}{l}1.28 \\
(1.05 \text { to } 1.5)\end{array}$ & $\begin{array}{l}1.19 \\
(1.9 \text { to } 1.3)\end{array}$ & NS & NS \\
\hline $\begin{array}{l}\text { Systolic BP }(\mathrm{mm} \mathrm{Hg}) \\
\text { Diastolic BP }(\mathrm{mm} \mathrm{Hg})\end{array}$ & $\begin{array}{l}132 \cdot 6(5 \cdot 7) \\
80 \cdot 2(2 \cdot 1)\end{array}$ & $\begin{array}{l}142 \cdot 7(4 \cdot 2) \\
81 \cdot 6(1 \cdot 7)\end{array}$ & $\begin{array}{l}138.0(6 \cdot 2) \\
82.6(2 \cdot 4)\end{array}$ & $\begin{array}{l}129.7(4 \cdot 0) \\
79 \cdot 4(1 \cdot 2)\end{array}$ & $\begin{array}{l}\text { NS } \\
\text { NS }\end{array}$ & $\begin{array}{l}\text { NS } \\
\text { NS }\end{array}$ \\
\hline
\end{tabular}

$\mathrm{HDL}=$ High density lipoprotein; $\mathrm{BP}=$ blood pressure.

Table 11 Pearson correlation coefficients between waist to hip ratio, lipids, and insulin concentrations

\begin{tabular}{|c|c|c|c|c|c|c|}
\hline & \multicolumn{2}{|c|}{ White subjects } & \multicolumn{2}{|c|}{ British Asians } & \multicolumn{2}{|c|}{ Indian Asians } \\
\hline & $\begin{array}{l}\text { Patients } \\
(n=87)\end{array}$ & $\begin{array}{l}\text { Controls } \\
(n=81)\end{array}$ & $\begin{array}{l}\text { Patients } \\
(n=83)\end{array}$ & $\begin{array}{l}\text { Controls } \\
(n=80)\end{array}$ & $\begin{array}{l}\text { Patients } \\
(n=30)\end{array}$ & $\begin{array}{l}\text { Controls } \\
(n=30)\end{array}$ \\
\hline $\begin{array}{l}\text { Total cholesterol } \\
\text { Log HDL cholesterol } \\
\text { Log triglyceride } \\
\text { Log insulin }\end{array}$ & $\begin{array}{r}0.08 \\
-0.16 \\
0.15\end{array}$ & $\begin{array}{c}0.18 \\
-0.27^{\star} \\
0.23^{\star}\end{array}$ & $\begin{array}{c}-0.008 \\
0.003 \\
0.19\end{array}$ & $\begin{array}{c}0.22 \\
-0.03 \\
0.29 \dagger\end{array}$ & $\begin{array}{l}0 \cdot 34 \\
0 \cdot 37^{\star} \\
0 \cdot 36^{\star}\end{array}$ & $\begin{array}{r}0.18 \\
-0.01 \\
0.33\end{array}$ \\
\hline $\begin{array}{l}\text { Fasting } \\
\text { One hour } \\
\text { Two hours }\end{array}$ & $\begin{array}{l}0.38 \dagger \\
0.17 \\
0.38 \dagger\end{array}$ & $\begin{array}{l}0.20 \\
0.32 \dagger \\
0.24\end{array}$ & $\begin{array}{l}0.43 \dagger \\
0.20 \\
0.32 \dagger\end{array}$ & $\begin{array}{l}0.44 \dagger \\
0.27^{\star} \\
0.50 \dagger\end{array}$ & $\frac{0.10}{0.13}$ & $\frac{0.21}{0.41 \star}$ \\
\hline
\end{tabular}

$\star \mathrm{P}<0.05 .+\mathrm{P}<0.01$.

Table 12 Univariate effects of insulin, glucose, Body mass index, waist to hip ratio, and lipids on relative risk of coronary atherosclerosis

\begin{tabular}{|c|c|c|c|c|c|c|c|c|c|}
\hline & \multicolumn{3}{|c|}{ White subjects } & \multicolumn{3}{|c|}{ British Asians } & \multicolumn{3}{|c|}{ Indian Asians } \\
\hline & $\begin{array}{l}\text { Relative } \\
\text { risk }\end{array}$ & $\begin{array}{l}\text { Relative risk } \\
\text { for increase of } \\
\text { one unit }(95 \% \text { CI) }\end{array}$ & $P$ Value & $\begin{array}{l}\text { Relative } \\
\text { risk }\end{array}$ & $\begin{array}{l}\text { Relative risk } \\
\text { for increase of } \\
\text { one unit ( } 95 \% \text { CI) }\end{array}$ & $P$ Value & $\begin{array}{l}\text { Relative } \\
\text { risk }\end{array}$ & $\begin{array}{l}\text { Relative risk } \\
\text { for increase of } \\
\text { one unit }(95 \% \text { CI) }\end{array}$ & PValue \\
\hline \multicolumn{10}{|l|}{ Log Insulin } \\
\hline Fasting & $2 \cdot 8$ & $\begin{array}{l}1.7 \text { to } 4.8 \\
1.4 \text { to } 3.7\end{array}$ & $<0.0001$ & $4 \cdot 0$ & $2 \cdot 1$ to $7 \cdot 8$ & $<0.0001$ & $4 \cdot 4$ & $1 \cdot 2$ to 17 & 0.02 \\
\hline $\begin{array}{l}\text { One hour } \\
\text { Two hours }\end{array}$ & $\begin{array}{l}2 \cdot 2 \\
2 \cdot 0\end{array}$ & $\begin{array}{l}1.4 \text { to } 3.7 \\
1.4 \text { to } 3.0\end{array}$ & $\begin{array}{l}0.0009 \\
0.0002\end{array}$ & $\begin{array}{l}2 \cdot 2 \\
2 \cdot 5\end{array}$ & $\begin{array}{l}1.3 \text { to } 3.7 \\
1.4 \text { to } 4.2\end{array}$ & $\begin{array}{c}<0.003 \\
0.0005\end{array}$ & $\overline{2 \cdot 3}$ & $\overline{1 \cdot 1}$ to $5 \cdot 1$ & $\overline{0}_{0.03}$ \\
\hline \multicolumn{10}{|l|}{ Log glucose } \\
\hline Fasting & $4 \cdot 4$ & $1 \cdot 1$ to $1 \cdot 7$ & 0.025 & $1 \cdot 8$ & 0.7 to 4.7 & $0 \cdot 21$ & $2 \cdot 6$ & 0.5 to 13 & $0 \cdot 22$ \\
\hline One hour & 1.9 & 0.7 to 4.9 & 0.21 & $3 \cdot 2$ & 1.2 to 8.3 & $<0.01$ & - & - & - \\
\hline Two hours & $3 \cdot 1$ & $1 \cdot 3$ to $7 \cdot 2$ & 0.006 & $2 \cdot 1$ & 1.0 to $4 \cdot 3$ & 0.04 & 1.8 & 0.5 to 6.3 & 0.32 \\
\hline Log triglyceride & $4 \cdot 0$ & 1.9 to 8.2 & $<0.0001$ & $3 \cdot 6$ & $1 \cdot 7$ to $7 \cdot 7$ & 0.003 & $7 \cdot 1$ & 1.6 to 31 & 0.0003 \\
\hline Cholesterol & $1 \cdot 2$ & 0.9 to 1.7 & $0 \cdot 16$ & $1 \cdot 6$ & $1 \cdot 2$ to $2 \cdot 2$ & 0.0003 & 1.4 & 0.9 to 2.4 & $0 \cdot 15$ \\
\hline HDL cholesterol & $1 \cdot 2$ & 0.9 to $1.7^{\star}$ 太 & $<0.0001$ & 0.92 & 0.8 to $1 \cdot 1^{\star}$ & 0.22 & 0.60 & 0.45 to $0.81^{\star}$ & $<0.0001$ \\
\hline Cholesterol/HDL ratio & $1 \cdot 5$ & 1.2 to 1.8 & $<0.0001$ & $1 \cdot 4$ & 1.1 to 1.8 & $<0.002$ & $3 \cdot 8$ & 1.9 to 7.8 & $<0.0001$ \\
\hline Body mass index & $1 \cdot 1$ & $1 \cdot 0$ to $1 \cdot 2$ & 0.08 & $1 \cdot 1$ & 0.9 to 1.1 & 0.3 & $1 \cdot 0$ & 0.9 to 1.2 & 0.53 \\
\hline Waist to hip ratio & $1 \cdot 7$ & $1 \cdot 0$ to $1 \cdot 9^{\star}$ & 0.061 & $3 \cdot 3$ & 1.9 to $5 \cdot 7^{\star}$ & $<0.0001$ & 2.5 & $1 \cdot 1$ to $6 \cdot 0^{\star}$ & 0.025 \\
\hline Diabetes & $3 \cdot 4$ & 0.7 to 1.7 & $0 \cdot 10$ & $2 \cdot 5$ & 1.0 to 5.9 & 0.035 & $\mathbf{2} \cdot \mathbf{5}$ & 0.7 to 8.7 & $0 \cdot 13$ \\
\hline
\end{tabular}

* Per $0 \cdot 1$ unit increase.

$\mathrm{HDL}=$ High density lipoprotein; $\mathrm{CI}=$ confidence interval 
Table 13 Univariate effects of insulin on relative risk of coronary atherosclerosis in Asians, excluding patients with diabetes

\begin{tabular}{|c|c|c|c|c|c|c|}
\hline & \multicolumn{3}{|c|}{ British Asians } & \multicolumn{3}{|c|}{ Indian Asians } \\
\hline & $\begin{array}{l}\text { Relative } \\
\text { risk }\end{array}$ & $\begin{array}{l}\text { Relative risk } \\
\text { for increase of } \\
\text { P value one unit } \\
(95 \% \text { CI })\end{array}$ & $P$ Value & $\begin{array}{l}\text { Relative } \\
\text { risk }\end{array}$ & $\begin{array}{l}\text { Relative risk } \\
\text { for increase of } \\
\text { P value one unit } \\
(95 \% \mathrm{CI})\end{array}$ & P Value \\
\hline $\begin{array}{l}\text { Log insulin: } \\
\text { Fasting } \\
\text { One hour } \\
\text { Two hour }\end{array}$ & $\begin{array}{l}7 \cdot 9 \\
5 \cdot 6 \\
4 \cdot 5\end{array}$ & $\begin{array}{l}3.2 \text { to } 19 \\
2.5 \text { to } 12 \\
2.2 \text { to } 9 \cdot 1\end{array}$ & $\begin{array}{l}<0.0001 \\
<0.0001 \\
<0.0001\end{array}$ & $\frac{31}{3 \cdot 5}$ & $\begin{array}{l}\frac{2.8}{1} \text { to } 340 \\
1.2 \text { to } 9.9\end{array}$ & $\begin{array}{l}<0.0005 \\
-0.008\end{array}$ \\
\hline
\end{tabular}

$\mathrm{CI}=$ Confidence interval.

Table 14 Multivariate analysis showing independent predictors of coronary atherosclerosis

\begin{tabular}{|c|c|c|c|}
\hline & $\begin{array}{l}\text { Relative } \\
\text { risk }\end{array}$ & $\begin{array}{l}\text { Relative risk for } \\
\text { One unit increase } \\
(95 \% \mathrm{CI})\end{array}$ & $P$ Value \\
\hline \multicolumn{4}{|l|}{ White subjects } \\
\hline $\begin{array}{l}\text { Log Insulin (fasting) concentration } \\
\text { Log HDL cholesterol concentration }\end{array}$ & $\begin{array}{l}2 \cdot 4 \\
0 \cdot 84\end{array}$ & $\begin{array}{l}1.4 \text { to } 4.3 \\
0.72 \text { to } 9.98^{\star}\end{array}$ & $\begin{array}{r}<0.0001 \\
0.0007\end{array}$ \\
\hline \multicolumn{4}{|l|}{ British Asians } \\
\hline Waist to hip ratio & $4 \cdot 1$ & $2 \cdot 2$ to $7 \cdot 7^{\star}$ & $<0.0001$ \\
\hline \multicolumn{4}{|l|}{ Indian Asians } \\
\hline Waist to hip ratio & $3 \cdot 1$ & 0.9 to 10.4 & 0.009 \\
\hline Log HDL cholesterol concentration & 0.53 & 0.36 to 0.77 & $<0.0001$ \\
\hline
\end{tabular}

$\star$ Per $0 \cdot 1$ unit increase.

CI $=$ Confidence interval; HDL $=$ high density lipoprotein

Indian Asian controls. The timing of lipid measurements was different in the subgroup from India; this may have affected the high density lipoprotein cholesterol concentration. ${ }^{13}$

Cholesterol concentrations were significantly higher in Asian patients from Britain than in patients from India. Concentrations were similar in the patient groups compared with their respective control groups.

Cholesterol (total cholesterol/high density lipoprotein cholesterol) was significantly higher in all patient groups compared with their controls (table 6).

\section{RELATION BETWEEN EXERCISE AND INSULIN CONCENTRATIONS}

There were significant differences between sedentary and non-sedentary subjects. Body mass index, systolic and diastolic blood pressures, triglycerides, and insulin concentrations during fasting and at one and two hours after glucose by mouth were significantly lower in subjects who were more active (table 7). Indian Asians had the largest proportion of non-sedentary subjects followed by white patients; British Asians had the lowest proportion (table 1).

Data were further analysed for each ethnic group (tables 8-10) and this also showed clear differences between the physically active and inactive groups.

\section{RELATION BETWEEN WAIST TO HIP RATIO,} INSULIN, AND LIPIDS

There was a significant positive correlation between the waist to hip ratio and insulin in most patient and control groups at one or more times of the oral glucose tolerance test. High density lipoprotein cholesterol showed a negative, and triglyceride a positive, correlation with the waist to hip ratio (table 11).
UNIVARIATE EFFECTS ON RELATIVE RISK OF CORONARY ATHEROMA AND MULTIVARIATE ANALYSIS

Table 12 shows the univariate effects of various variables on the relative risk of coronary atheroma in the three patient groups.

In Asians these were also computed separately in non-diabetic subjects to see whether a higher prevalence of diabetes in Asians was overshadowing other risk factors (table 13). In white patients fasting glucose, triglyceride, and insulin concentrations showed the strongest association. In British Asians, fasting insulin followed by triglyceride concentration and the waist to hip ratio showed the strongest association; in Indian Asians, triglyceride and then fasting insulin concentration, cholesterol ratio, and the waist to hip ratio showed the strongest association. In the combined Asian groups, on excluding the diabetic patients, the relative risk from insulin is greatly increased.

In multiple regression analysis (table 14), fasting insulin and high density lipoprotein cholesterol concentrations were independent predictors of coronary atherosclerosis in white men, whereas in British Asians the waist to hip ratio was the strongest independent predictor; high density lipoprotein cholesterol concentrations and waist to hip ratio were independent predictors in Indian Asians.

\section{Discussion}

All the patients studied had angiographically proved significant coronary atherosclerosis. Asians studied in India were from the same geographical area from which most of the Asians studied in the United Kingdom had migrated. This study confirms the presence of hyperinsulinaemia, glucose intolerance, low plasma high density lipoprotein cholesterol, and high triglyceride concentrations in this subgroup of Punjabi Asians. Similar abnormalities have been reported in various other subgroups of Asians, ${ }^{714}$ however, a comparative analysis of these abnormalities between Asians in the United Kingdom and in India has not been reported previously.

In this study insulin concentrations were measured in the fasting state and one and two hours after glucose given by mouth. At all stages clear differences were seen in insulin concentrations between and within each of the three racial groups. Concentrations in Asians from the United Kingdom and in India were similar, except in the fasting state. This suggests that insulin resistance may be mainly a genetic defect in this subgroup of Asians. Obesity, however, another variable which is under environmental control, was no different in the Asian group from United Kingdom than in Asians from India. This could be due to the predominently urban groups of Indian Asians in this study. Further comparison with rural Indians would be more revealing. Similar findings in second generation Japanese-American non-insulin dependent diabetic men were seen compared with Japanese men in Tokyo. ${ }^{12}$ 
In this study central obesity, evidenced by a higher waist to hip ratio, showed a significant correlation with hyperinsulinaemia in Asians and white men; however, only in Asians did it pose a significant relative risk of coronary atherosclerosis. Multivariate analysis showed central obesity to be the most powerful single predictor of coronary atherosclerosis in British Asians and the second most powerful predictor in Indian Asians. Two recent population studies $^{67}$ in the United Kingdom in which most of the subjects were from the Punjabi region of the Indian subcontinent have shown a similar striking tendency to central obesity. In the study by McKeigue et $a{ }^{7}{ }^{7}$ Gujaratis had a similar high waist to hip ratio to other subgroups of Asians. Thus this tendency of central obesity may be universally present in the various subgroups of Asians, but the risk of coronary artery disease or myocardial infarction mediated through it may be different. This study is a case control study and thus there remains a possibility that risk factors in the patient groups may alter after the onset of the disease.

Evans et al ${ }^{15}$ have shown a positive correlation between increasing degrees of insulin resistance and the waist to hip ratio; a similar correlation was noted in our study.

Central obesity may mediate insulin resistance and its effects through various routes. Fractional hepatic extraction of insulin is reduced in central obesity, thus producing greater posthepatic delivery of insulin. ${ }^{16}$ Hypertrophied fat cells associated more with central obesity show resistance to insulin action in vitro ${ }^{17}$ and hypertriglyceridaemia is associated more with central rather than lower body obesity of equal degree. ${ }^{1518}$ Prospective studies $^{1920}$ also support central obesity as a cardiovascular risk factor.

Insulin, apart from the mediation of lipid abnormalities, ${ }^{21}$ has an effect on the cells important in the pathogenesis of atherosclerosis. It promotes the proliferation of cultured smooth muscle cells. ${ }^{22}$ Insulin may act directly ${ }^{23}$ or indirectly through the stimulation of growth factors. ${ }^{22} 24$

The beneficial effects of exercise or physical activity are clearly seen in this study. Subjects who were physically active had significantly lower insulin concentrations, body mass index, triglyceride concentrations, and there were favourable effects on systolic and diastolic blood pressure. Indian Asians were the most active, followed by white men, and the least physical activity was recorded in British Asians. Another study has also suggested that habitual aerobic exercise reduces central obesity. ${ }^{25}$ The evidence of the present study suggests that promotion of physical activity in the Asian community in the United Kingdom should be an important measure to protect against coronary artery disease.

Knight $e t a l^{6}$ and McKeigue et $a l^{7}$ speculate that insulin resistance in Asians may be an adaptive energy conserving mechanism under conditions of periodic famine and low energy intake, and the increased incidence of diabetes and other disturbances associated with insulin resistance noted in migrant Asians may be consequences of their transportation into urban British life, together with a high energy intake. Our data do not fully support this supposition. Similar high insulin concentrations were seen in Asians in the United Kingdom and in India, suggesting that the environment is not making an appreciable difference. Adaptive mechanisms, however, in any population, take a long time to operate, ${ }^{26}$ also agriculture has been the main occupation of the population in India for centuries and the food supply has been plentiful apart from the latter part of this millenium.

In the present study Indian Asians were mainly recruited from an urban setting; however, they were still more physically active than other groups. In rural India where most subjects follow agricultural occupations with a high level of physical activity, the prevalence of coronary artery disease has been shown to be low. ${ }^{27}$ High levels of physical activity thus may act as a "protective" mechanism again the deleterious effects of this predisposition to higher insulin concentrations.

Further evidence that predisposition to insulin resistance in Asian migrants may be mainly genetic comes from an historical perspective. The Indus Valley civilisation vanished without trace around the second millennium BC. Its disappearance is almost certainly linked with the rise of a population group, the Nordics, normally known as the Aryans, who were most probably invaders from northern Iran and had earlier broken off from the main nomad tribes in south Russia. ${ }^{28}$ Studies showing the presence of insulin resistance in Asians overseas, including ours, have been in subgroups of Asians migrating mainly from the north, northwest, and northeast of the Indian subcontinent belonging to the Aryan population group, thus having a common genetic pool. The other major population group in India is the Dravidian, who reside mostly in the southern part of India. It will be interesting to know if people of Dravidian origin in India also show this predisposition. Studies to define possible gene markers (currently under way) in Asians may contribute most to a better understanding of this predisposition.

1 McKeigue PM, Miller GJ, Marmot MG. Coronary heart disease in South Asians overseas-review. $f$ Clin Epidermiol 1989;42:597-609.

2 OPCS. Mortality and geography: a review in the mid-1980's. The Registrar-General's decennial supplement for England and Wales, series DS No 9. London: HMSO, 1990.

3 Balarajan R, Adelstein AM, Bulusu L, Shukla V. Patterns of mortality among migrants to England and Wales from the Indian sub-continent. $B M \mathscr{F} 1984 ; 289: 1185-7$.

4 McKeigue PM, Marmot MG. Mortality from coronary heart disease in Asian communities in London. BMF 1988;297:903.

5 Hughes LO, Cruickshank J, Wright, Raftery EB. Disturbances of insulin in British Asian and white men Disturbances of insulin in British Asian and white men
surviving myocardial infarction. BMf 1989;299:537-41.

6 Knight TM, Smith Z, Whittles A, et al. Insulin resistance, diabetes and risk markers for ischaemic heart disease in Asians and non-Asians in Bradford. Br Heart $¥ 1992$; 67:343-50.

7 McKeigue PM, Shah B, Marmot MG. Relationship of central obesity and insulin resistance with high diabetes prevalence and cardiovascular risk in South Asians. Lancet 1991;337:382-6.

8 Hughes LO, Ravel U, Raftery EB. First myocardial infarction in Asian and white men. BMF 1989;298:1345-50. 
9 Stern MP, Haffner SM. Body fat distribution and hyperinsulinaemia as risk factors for diabetes and cardiovascular disease. Atherosclerosis 1986;6:123-30.

10 Neusy AJ, Lavenstein J. Effects of prazosin, atenolol and thiazide diuretic on plasma lipids in patients with essential hypertension. $A m \mathcal{F}$ Med 1984;80(suppl 2A):94-9.

11 Grimm RH, Leun AS, Hunninghake DB, Lenz $\mathrm{K}$, Hannan P, Blackburn H. Effects of thiazide diuretics on plasma lipids and lipoproteins in mildly hypertensive plasma lipids and lipoproteins in mild
patients. Ann Intern Med 1981;99:7-11.

12 Fujimoto WY, Akanuma Y, Kanazawa Y, Mashiko S, Leonetti D, Wahl P. Plasma insulin levels in Japanese and Japanese-American men with type- 2 diabetes may be related to the occurrence of cardiovascular disease. Diab Res Clin Pract 1989;6:121-7.

13 Bainton B, Burns-Cox CJ, Elwood PC, et al. Prevalence of ischaemic heart disease and associations with serum lipoproteins in subjects aged 45-64 years: the Speedwel Study. Br Heart F 1982;47:483-9.

14 McKeigue PM, Marmot MG, Syndercombe Court YD, Rahman S, Riemersma RA. Diabetes, hyperinsulinaemia and coronary risk factors in Bangladeshis in East and coronary risk factors in Bang

15 Evans DJ, Hoffman RG, Kalkhoff RK, Kissebah AH Relationship of body fat topography to insulin sensitivity and metabolic profiles in premenopausal women. Metabolism 1984;33:68-75.

16 Kissebah AH, Evans DJ, Peiris A, Wilson CR. Endocrine characteristics in regional obesities: role of sex steroids. Proceedings of the International Symposium on the Metabolic Complications of Human Obesity; 1985; Marseille. ICS No 682. Amsterdam: Elsevier, 1986.

17. Olefsky JM. The insulin receptor. Its role in insulin resistance of obesity and diabetes. Diabetes 1976;25:1154-62.

18 Stern MP, Wood PD, King A, Osnan K, Farquhar JW, Silvers A. Morphological and temporal characteristics of obesity as determinants of plasma triglycerides in a free living population. Symposium on the Regulation of the living population. Symposium on the Regulation of the
Adipose Tissue Mass. IVth International Meeting of
Endocrinology; Marseilles. Excerpta International Congress Series. Vol 315. 1974, 316-9.

19 Larsson B, Svardsudd K, Welin L, Wilhelmsen L Bjorntorp P, Tibblin B. Abdominal adipose tissue distribution, obesity and risk of cardiovascular disease and death; a 13-year follow up of participants in the study of men born in 1913. BMF 1984;288:1401-4.

20 Lapidu I Bengs Sidus L, Bengtsson C, Larsson B, Pennert K, Rybo E,
Sistribution of adipose tissue and risk of costrom $L$. Distribution of adipose tissue and risk of cardiovascular disease and death: a 12-year follow up of participants in the population study of wom

21 Defronzo A, Ferrannini E. Insulin resistance: a multifaceted syndrome responsible for NIDDM, obesity, hyperension, dislipidemia, and atherosclerotic cardiovascular disease. Diabetes Care 1991;14:173-86.

22 Pfeifle B, Ditschunet H. Effect of insulin on the growth of cultured arterial smooth muscle cells. Diabetologia 1981; 20:155-8.

23 Kleinman KS, Fine LG Pronostic implications of renal hypertrophy in diabetes mellitus. Diabetes Metab Rev 1988;4:179-89.

24 Banskota NK, Taub R, Zeliner K, Olsen P, King GL and cellular growth in human vascular smooth muscle and cellular growth in human vascular smooth m

25 Wood PD. Treatment of hypertriglyceridemia by exercise [abstract]. Presented at the meeting; "Triglycerides, the ole in diabetes and atherosclerosis". Vienna, Austria, 1990.

26 Nei M, Roychoudhury AD. Genetic relationship and evoiution of human races. Evolutionary Biology 1982:14: $1-59$

27 Jajoo UN, Kalantri SP, Gupta OP, Jain AP, Gupta K. The prevalence of coronary heart disease in rural population from central India. $\exists$ Assoc Physicians India 1988;12: from cen

28 Stone N, ed. Atlas of world history. 3rd ed. Guild Publishing, 1990. 